\title{
Comparison of Surface Characteristics of Mesoporous Titania Prepared in Matrix-Free Solutions and Using Triton X Reverse Micelles
}

\author{
Polyxeni Paschalidou, Charis R. Theocharis* \\ Porous Solids Group, Department of Chemistry, University of Cyprus, Nicosia, Cyprus \\ Email: *charis@ucy.ac.cy
}

How to cite this paper: Paschalidou, P. and Theocharis, C.R. (2020) Comparison of Surface Characteristics of Mesoporous Titania Prepared in Matrix-Free Solutions and Using Triton X Reverse Micelles. Materials Sciences and Applications, 11, 715-732. https://doi.org/10.4236/msa.2020.1111048

Received: August 3, 2020

Accepted: November 3, 2020

Published: November 6, 2020

Copyright $\odot 2020$ by author(s) and Scientific Research Publishing Inc. This work is licensed under the Creative Commons Attribution International License (CC BY 4.0).

http://creativecommons.org/licenses/by/4.0/

\begin{abstract}
Titania nanoparticles have been prepared from the precursor compound $\mathrm{Ti}(\mathrm{OiPr})_{4}$ using Triton $\mathrm{X}$ reverse micelles with varying surfactant tail, in a matrix-free aqueous ( $\mathrm{pH}$ 2) and in non-aqueous phase (benzyl alcohol and glacial acetic acid, solvothermal method). The importance of this work lies in the further elucidation in the synthetic methodology of preparing well-characterized nanoporous solids. Comparison of the texture characteristics and surface properties of the samples prepared from each technique, was carried out using physicochemical techniques: pXRD, BET/DFT/BJH, FTIR, DRUV-Vis and SEM. The results show that the use of Triton X reverse micelles with varying surfactant size results in $\mathrm{TiO}_{2}$ solids with adjustable surface characteristics in contrast to matrix-free. Specifically, samples of the latter methods present higher surface area values at lower calcination temperatures but present reduced thermal stability and control of their surface properties.
\end{abstract}

\section{Keywords}

Titanium Dioxide, Surface Characteristics, Mesopores, Inverse Micelles, Synthesis

\section{Introduction}

Titanium dioxide, $\mathrm{TiO}_{2}$, is one of the most interesting transition metal oxides because of the following properties: 1) high refractive indices of anatase (2.54) and rutile (2.79), which result in high surface reflectivity, 2) high surface area which leads to a higher density of localized states, composed of electrons with energies between the conduction and valence bands, 3) relatively slow rate of 
charge carrier recombination and energy gaps beyond $3.0 \mathrm{eV}, 4)$ facile interconversion of the +3 and +4 oxidation states, and 5) high absorption in the ultraviolet region of the spectrum. Titania occurs in the form of two important polymorphs, the metastable anatase and stable rutile. These polymorphs exhibit different properties and consequently different photocatalytic performances. Anatase is irreversibly transformed to rutile at elevated calcination temperatures [1] [2].

The main industrial applications of titania are as white pigment in paints, food colouring, cosmetics, toothpastes, polymers etc., as filler in heterogeneous catalysis (promoter, catalytical substrate), in photocatalysis. Regarding the energy sector, titania is employed in water electrolysis for hydrogen production and dye-sensitised solar cells (DSSCs). In addition, $\mathrm{TiO}_{2}$ finds application in decontamination technologies and waste-water treatment as adsorbent [1] [3] [4] [5] [6]. In this context, the study of possible synthetic procedures for preparation of mesoporous titania solids with high surface area and adjustable mesoporous structure is of particular interest in both catalytic applications and environmental decontamination technologies [7] [8] [9] [10].

Among the matrix-based synthesis techniques used, the reverse microemulsions belong to the category of combined colloidal systems, which allow particle size and consequently surface area control of $\mathrm{TiO}_{2}$ solids [11] [12] [13] [14] [15]. Generally, the use of surfactants (e.g. Triton X), offers in addition to the steric stabilization, adjustable micro-environment of the reaction and subsequently particle growth control and selectivity towards certain crystalline phases [16] [17] [18] [19] [20].

Regarding the matrix-free methods in aqueous and organic solutions, there are many bibliographic data that describe synthetic pathways of $\mathrm{TiO}_{2}$ solids resulting in high surface area related to the porosity and particle size of the solids [17] [21]. The matrix-free methods are the solvothermal and hydrothermal processes, pyrolysis, thermal decomposition, aqueous alkalic/acidic precipitation, liquid, and solid combustion techniques, mechanochemical and electrochemical methods, sol-gel procedure, gas phase condensation, microwaves heating synthesis and ultrasound methods. Among the different matrix-free methods the present study is focused on two synthetic processes 1) the colloid formation in aqueous acidic solutions ( $\mathrm{pH} 2$ ) and 2) the solvothermal method using benzyl alcohol and dried acetic acid.

The formation of titania nanocolloids is achieved successfully by hydrolysis and condensation of titanium alkoxides in aqueous media. The hydrolysis of the precursor compound in the presence of excess water is fast and is completed in seconds [22]. The formation of titania colloids at high $\mathrm{r}$ ratios $\left(\mathrm{r}=\left[\mathrm{H}_{2} \mathrm{O}\right] /[\mathrm{M}]\right)$ is of interest, because under such conditions small size particles are formed. Furthermore, the solution $\mathrm{pH}$ strongly affects the size distribution of the nanoparticles. At pH 2 a homogenous supernatant of well-formed particles is created, whereas at solution $\mathrm{pH}>2$ the reaction results in the formation of ill-formed solid phases [21] [23] [24] [25] [26]. 
The solvothermal synthesis includes organic solvents both as catalysts and occasionally as components of the solid phases at increased temperature $\left(>100^{\circ} \mathrm{C}\right)$ and pressure (several bars) [27]. The solvothermal process can be defined as chemical reaction or transformation in an organic solvent like methanol [28], 1,4-butanol [29], toluene [30] under supercritical conditions [31]. The particle morphology, crystalline phase and surface chemistry of the solids could be controlled by adjusting the precursor composition, reaction temperature, pressure, solvent properties and aging time [32] [33]. The solvothermal method provides excellent chemical homogeneity and the possibility to form unique metastable structures at low reaction temperatures [31]. The use of solution additives governs crystalline growth and prevents particle aggregation due to the effective dispersion of nano-crystallites [21] [34] [35] [36].

The present study aims to compare of texture and surface characteristics of mesoporous $\mathrm{TiO}_{2}$ solids prepared using Triton $\mathrm{X}$ reverse micelles of varying tail size matrix and $\mathrm{TiO}_{2}$ solids synthesized in matrix-free systems 1) through aqueous precipitation at $\mathrm{pH} 2$ and 2) by a solvothermal method in a non-aqueous phase.

\section{Experimental}

\subsection{Reverse Micelle-Mediated Synthesis of Titania}

The titania gels have been prepared by mixing the $\mathrm{Ti}\left(\mathrm{O}^{i} \mathrm{Pr}\right)_{4}$ precursor compound with the three different reversed micelle mixtures of Triton X-100 (extra pure, Fisher Chemical), Triton X-114 (extra pure, Sigma-Aldrich) and Triton $\mathrm{X}-45$ (extra pure, Sigma-Aldrich) as described elsewhere [17].

\subsection{Synthesis of Titania Colloids in Aqueous Media $(\mathrm{pH}=2)$}

For comparison purposes titania nano-particles prepared by modified method of hydrolysis and digestion $\mathrm{Ti}\left(\mathrm{O}^{\mathrm{i}} \mathrm{Pr}\right)_{4}$ solution [23]. Initially, the precursor solution resulted from the addition of $5 \mathrm{ml} \mathrm{Ti}\left(\mathrm{O}^{\mathrm{i}} \mathrm{Pr}\right)_{4}$ in $15 \mathrm{ml}$ isopropanol (99.95\%, Fisher Chemical). Separately, an aqueous solution, which constitutes the hydrolysis catalyst, is formed by the dropwise addition of $8 \mathrm{M} \mathrm{HNO}_{3}$ (70\%, Sigma-Aldrich Chemical) in $250 \mathrm{ml}$ de-ionized water until the $\mathrm{pH}$ is 2 . The gel formation procedure started by the mixing of two mentioned above solutions under vigorous stirring. The hydrolysis of $\mathrm{Ti}\left(\mathrm{O}^{\mathrm{i}} \mathrm{Pr}\right)_{4}$ produced a turbid, milky, colloidal solution, which was heated at $65^{\circ} \mathrm{C}$ overnight. The resulting suspension had a relatively high viscosity and a white-blue tint. Afterwards, the collected precipitate was washed several times with high purity ethanol (99.5\%, Sigma-Aldrich) and dried at $100^{\circ} \mathrm{C}$ under vacuum for several hours. In the end, parts of dried solid were calcined at temperatures $400^{\circ} \mathrm{C}, 500^{\circ} \mathrm{C}, 600^{\circ} \mathrm{C}$ and $700^{\circ} \mathrm{C}$ with temperature increase rate $6^{\circ} \mathrm{C} / \mathrm{min}$ for $2 \mathrm{~h}$.

\subsection{Solvothermal Synthesis of $\mathrm{TiO}_{2}$ Using Benzyl Alcohol and Glacial Acetic Acid (Non-Aqueous Phase)}

For this synthesis a mixture of $10 \mathrm{ml}$ titanium isopropoxide (>97\%, Sig- 
ma-Aldrich), benzyl alcohol (99.0\%, Sigma-Aldrich) and glacial acetic acid $(100 \%$, Merck) at a molar ratio of 1:1:4, was employed as described in a previous work [16].

\section{Results and Discussion}

\subsection{Surface Characteristics of Titania Solids Calcined at $400^{\circ} \mathrm{C}$}

Figure 1 shows the $\mathrm{N}_{2}$ ad/desorption isotherms and the corresponding pore size distributions of titania solids prepared by different synthetic routes and calcined at $\left.400^{\circ} \mathrm{C}: 1\right) \mathrm{TiO}_{2}$ precipitation in aqueous solutions ( $\mathrm{pH} 2$ ), 2) solvothermal method and 3) reverse micelle-mediated preparation using Triton-X surfactants of three different tail lengths. According to Figure 1 and the associated data, which are summarized in Table 1, all isotherms are type IV (a) with H2 (b) hysteresis loop [37] [38]. Moreover, the $\mathrm{TiO}_{2}$ solids prepared by reverse micelles present significantly higher surface area and specific pore volume values and have smaller average pore diameters compared to $\mathrm{TiO}_{2}$ solids obtained from the matrix-free synthetic procedures. On the other hand, the isotherm of the solvothermal synthesized $\mathrm{TiO}_{2}$ presents larger $\mathrm{H}_{2}$ type hysteresis loop, shifted at higher partial pressures. As the corresponding pores size distributions (Figure 1, Table 1) indicate the solids prepared by the solvothermal method after calcination at $400^{\circ} \mathrm{C}$ exhibit a wider pore diameter distribution, with the mean diameter being around $16 \mathrm{~nm}$ [39]. The specific pore volume of the material has a value 0.393
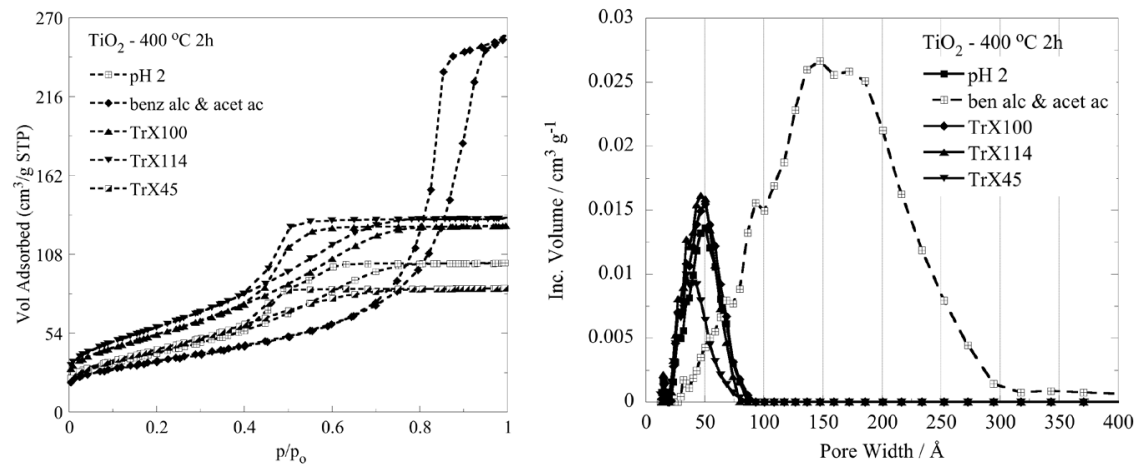

Figure 1. $\mathrm{N}_{2}$ adsorption isotherms and corresponding pores diameter distributions of $\mathrm{TiO}_{2}$ solids calcined at $400^{\circ} \mathrm{C}$, prepared by three different reverse micelles, hydrolysis in aqueous system and solvothermal synthesis.

Table 1. Porosity data of $\mathrm{TiO}_{2}$ solids prepared by three different reverse micelles, hydrolysis in aqueous system and solvothermal synthesis after calcination at $400^{\circ} \mathrm{C}$.

\begin{tabular}{ccccc}
\hline sample & $\mathrm{SpA}_{\mathrm{BET}}\left(\mathrm{m}^{2} / \mathrm{g}\right)$ & $\mathrm{V}_{\mathrm{Sp}}\left(\mathrm{cm}^{3} / \mathrm{g}\right)$ & $\mathrm{d}_{\mathrm{BJH}}(\mathrm{nm})$ & $\mathrm{d}_{\mathrm{DFT}}(\mathrm{nm})$ \\
\hline $\mathrm{TiO}_{2} \mathrm{pH}=2400^{\circ} \mathrm{C} 2 \mathrm{~h}$ & 139 & 0.158 & 3.38 & 5.06 \\
$\mathrm{TiO}_{2}$ benz alc \& acet ac $400^{\circ} \mathrm{C} 2 \mathrm{~h}$ & 121.1 & 0.393 & 10.01 & 16 \\
$\mathrm{TiO}_{2} \mathrm{TrX}-100400^{\circ} \mathrm{C} 2 \mathrm{~h}$ & 182.2 & 0.196 & 3.26 & 5.04 \\
$\mathrm{TiO}_{2} \mathrm{TrX}-114400^{\circ} \mathrm{C} 2 \mathrm{~h}$ & 199.3 & 0.201 & 3.14 & 4.67 \\
$\mathrm{TiO}_{2} \mathrm{TrX}-45400^{\circ} \mathrm{C} 2 \mathrm{~h}$ & 146.3 & 0.124 & 2.92 & 3.4 \\
\hline
\end{tabular}


$\mathrm{cm}^{3} / \mathrm{g}$ and the specific surface area is equal to $121.1 \mathrm{~m}^{2} / \mathrm{g}$. The solids obtained by the precipitation in acidic aqueous solution and by matrix-assisted formation show distributions which are significantly narrower (e.g. smaller area and specific pore volume), are shifted to lower pore diameter values with a mean pore diameter equal to $5.06 \mathrm{~nm}$.

This change in behaviour occurs because during the solvothermal method the formation of $\mathrm{TiO}_{2}$ particles takes place under high pressure (3 $\mathrm{MPa}$ ) and high temperature $\left(150^{\circ} \mathrm{C}\right)$ conditions resulting in greater crystallinity, smaller specific surface area and higher specific volume and mean pore diameter, due to the way the aggregation of primary particles occurs. Furthermore, the corresponding isotherm does not present any plateau at saturation pressure suggesting that the cohesion forces between the agglomerates are weak. Accordingly, the corresponding hysteresis loop (Figure 1) shifts at higher partial pressures. Nevertheless, the value of the specific surface area is relatively high $\left(121.1 \mathrm{~m}^{2} / \mathrm{g}\right)$ as the benzyl alcohol and glacial acetic acid complexes act partly as structure directing agent affecting the structure and porosity of the formed titanium oxides.

The sequence is Triton X-114 > Triton X-100 > Triton X-45 > pH $2>$ solvothermal method. The sequence for the homogeneous methods is due to cyclohexane extraction from the gels, since large amounts of organic residues are transferred from the gels and certainly from the inert of titania particles pores in the organic phase [40].

The diffraction peaks of XRD graphs (Figure 2) reflect the degree of crystallinity of the $\mathrm{TiO}_{2}$ solids obtained by the five different synthetic procedures and calcined at $400^{\circ} \mathrm{C}$ for 2 hours. According to the corresponding data, which are summarized in Table 2, the diffraction peaks of all solids indicate the formation of the thermally metastable anatase structure of $\mathrm{TiO}_{2}$ [41]. However, in the XRD diffractogram of the titania solids obtained from precipitation in acidic aqueous systems one additional peak appears at $30.58^{\circ}$, which is probably due to presence of small percent of rutile. Moreover, the diffraction peaks of these solids are very broad and of lower intensity ascribed to their colloidal/less crystalline structure. In contrast, the diffraction peaks of solvothermally prepared samples are more sharp and with higher intensity due to the higher crystallinity of the associated solids. The diffraction peaks of the matrix-assisted formation of $\mathrm{TiO}_{2}$ solids are significantly broader because of their lower crystallinity. According to the XRD data the crystallinity of the solids increases as follows: $\operatorname{TrX}-114<\operatorname{TrX}-45<$ $\operatorname{TrX}-100<\mathrm{pH} 2<$ solvothermal.

The infrared spectra of the solids (Figure 3, Table 3) show five characteristic peaks at $3430 \mathrm{~cm}^{-1}, 2346 \mathrm{~cm}^{-1}, 1626 \mathrm{~cm}^{-1}, 1391 \mathrm{~cm}^{-1}$ and $478 \mathrm{~cm}^{-1}$ which are attributed to the stretching vibrations of surface hydroxyl groups, vibrations of adsorbed $\mathrm{CO}_{2}$, bending vibrations of physisorbed water, surface residual organic groups or Ti-OH vibrations and stretching vibrations of Ti-O bonds of $\mathrm{TiO}_{2}$ crystal lattice [42] [43].

It has to be noted that the peak at $1391 \mathrm{~cm}^{-1}$ corresponding to the solvothermally prepared $\mathrm{TiO}_{2}$ solid presents higher intensity than the corresponding peak 


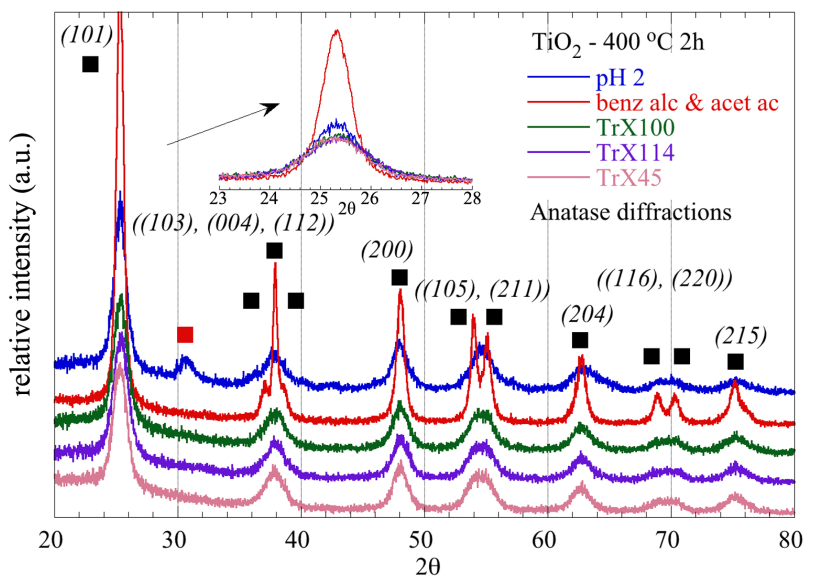

Figure 2. X-ray diffractograms of $\mathrm{TiO}_{2}$ samples calcined at $400^{\circ} \mathrm{C}$ for $2 \mathrm{~h}$ via three different Triton $\mathrm{X}$ reverse micelles, colloidal aqueous systems and solvothermal synthesis.

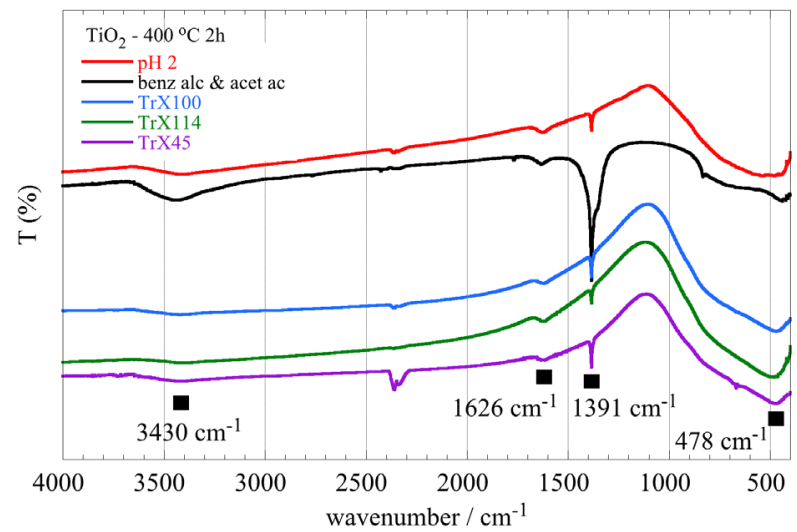

Figure 3. Infrared spectra of $\mathrm{TiO}_{2}$ samples calcined at $400^{\circ} \mathrm{C}$ for $2 \mathrm{~h}$ via three different reverse micelles, colloidal aqueous systems at $\mathrm{pH} 2$ and solvothermal method.

Table 2. XRD data of $\mathrm{TiO}_{2}$ solids calcined at $400^{\circ} \mathrm{C}$ for $2 \mathrm{~h}$ via three different reverse micelles, colloidal aqueous systems at $\mathrm{pH} 2$ and solvothermal method.

\begin{tabular}{ccccccc}
\hline sample & $\begin{array}{c}\mathrm{SpA}_{\mathrm{BET}} \\
\left(\mathrm{m}^{2} / \mathrm{g}\right)\end{array}$ & $\begin{array}{c}2 \theta_{\text {Bragg }} \\
\left({ }^{\circ}\right)\end{array}$ & level & $\begin{array}{c}\mathrm{d}_{\text {Bragg }} \\
(\AA)\end{array}$ & $\begin{array}{c}\mathrm{FWHM} \\
\left({ }^{\circ}\right)\end{array}$ & $\begin{array}{c}\mathrm{L}_{\mathrm{XRD}} \\
(\mathrm{nm})\end{array}$ \\
\hline $\mathrm{TiO}_{2} \mathrm{pH}=2400^{\circ} \mathrm{C} 2 \mathrm{~h}$ & 139 & 25.34 & $(101)$ & 3.5122 & 1.1633 & 7.32 \\
$\mathrm{TiO}_{2}$ benz alc \& acet ac $400^{\circ} \mathrm{C} 2 \mathrm{~h}$ & 121.1 & 25.35 & $(101)$ & 3.5111 & 0.6904 & 12.33 \\
$\mathrm{TiO}_{2} \mathrm{TrX}-100400^{\circ} \mathrm{C} 2 \mathrm{~h}$ & 182.2 & 25.37 & $(101)$ & 3.5082 & 1.3491 & 6.31 \\
$\mathrm{TiO}_{2} \mathrm{TrX}-114400^{\circ} \mathrm{C} 2 \mathrm{~h}$ & 199.3 & 25.39 & $(101)$ & 3.5048 & 1.4457 & 5.89 \\
$\mathrm{TiO}_{2} \mathrm{TrX}-45400^{\circ} \mathrm{C} 2 \mathrm{~h}$ & 146.3 & 25.33 & $(101)$ & 3.5139 & 1.3514 & 6.3 \\
\hline
\end{tabular}

observed for the other solids. Similarly, the band at $478 \mathrm{~cm}^{-1}$ is very extensive and somehow deformed because the corresponding solids are more crystalline, which is associated with increased number of $\mathrm{Ti}-\mathrm{O}-\mathrm{Ti}$ bonds due to extensive Ti-OH condensation. Generally, solids prepared through matrix-free synthetic procedures display more flattened band at $478 \mathrm{~cm}^{-1}$ than solids prepared with the use of matrices [44] [45]. 
Table 3. Bibliographic and experimental data of FTIR peaks of $\mathrm{TiO}_{2}$ solids via three different reverse micelles, colloidal aqueous systems and solvothermal method [42] [43] [44] [45].

\begin{tabular}{ccc}
\hline functional group & $\begin{array}{c}\text { bibliographical characteristic } \\
\text { absorption }\left(\mathrm{cm}^{-1}\right)\end{array}$ & $\begin{array}{c}\text { experimental characteristic } \\
\text { absorption }\left(\mathrm{cm}^{-1}\right)\end{array}$ \\
\hline stretching vibration of $\mathrm{H}_{2} \mathrm{O}$ & 3400 & 3430 \\
asymmetric stretch of $\mathrm{CO}_{2}$ & 2350 & 2346 \\
bending vibration of $-\mathrm{OH}^{-}$ & 1620 & 1626 \\
stretching vibration of & $1385 \& 1280$ & 4391 \\
COO \& Ti-O-C (or Ti-OH) & & 478 \\
stretching vibration of \\
Ti-O \& Ti-O-Ti \\
stretching vibration of Ti-O \& \\
Ti-O-Ti in rutile structure
\end{tabular}

\subsection{Effect of the Synthetic Path and Calcination at $500^{\circ} \mathrm{C}$ on the Texture Characteristics of $\mathrm{TiO}_{2}$}

Figure 4 includes nitrogen ad/desorption isotherms and pore diameter distributions of $\mathrm{TiO}_{2}$ samples prepared by five different synthetic paths and calcined at $500^{\circ} \mathrm{C}$. According to Figure 4 and the corresponding data summarized in Table 4 the solids prepared in matrix-free media present the highest BET surface area values and the order is as follows: $\mathrm{pH} 2>$ solvothermal $>\operatorname{TrX}-100>\operatorname{TrX}-114>$ TrX-45. This sequence is expected because even after calcination, organic residues originating from the reverse micelles are entrapped in the pores of $\mathrm{TiO}_{2}$. In addition, the mean values of pores diameters corresponding to solids prepared using micelles are smaller than the corresponding values of solid formed in matrix-free media.

This points out that the use of surfactants with different polar chain length can affect in a specific way the porous and surface characteristics of the formed solids. Besides the changes in particle size, the specific surface area, pore volume and mean diameter of pores decline with decreasing the length of the polar tail of reverse micelles. In contrast to solids synthesized in matrix-free media, which exhibit random porous characteristics with greater mean pores diameter, the corresponding solids prepared using surfactants present systematic shift to lower values regarding the pore diameter, peaks high of the pores size distributions and surface area (Figure 4) as follows: pH $2>$ solvothermal $>\operatorname{TrX}-100>$ $\operatorname{TrX}-114>\operatorname{TrX}-45$.

The XRD data corresponding to the five titania solids obtained from the five different synthetic paths and after calcination at $500^{\circ} \mathrm{C}$ for $2 \mathrm{~h}$ (Figure 5) are in full agreement with the previous results. In addition, the XRD peaks of the solids obtained from the solvothermal method and the use of reverse micelles present sharp peaks, have higher intensity and correspond to the anatase structure [46]. On the other hand, the XRD peaks corresponding to solids obtained from the 

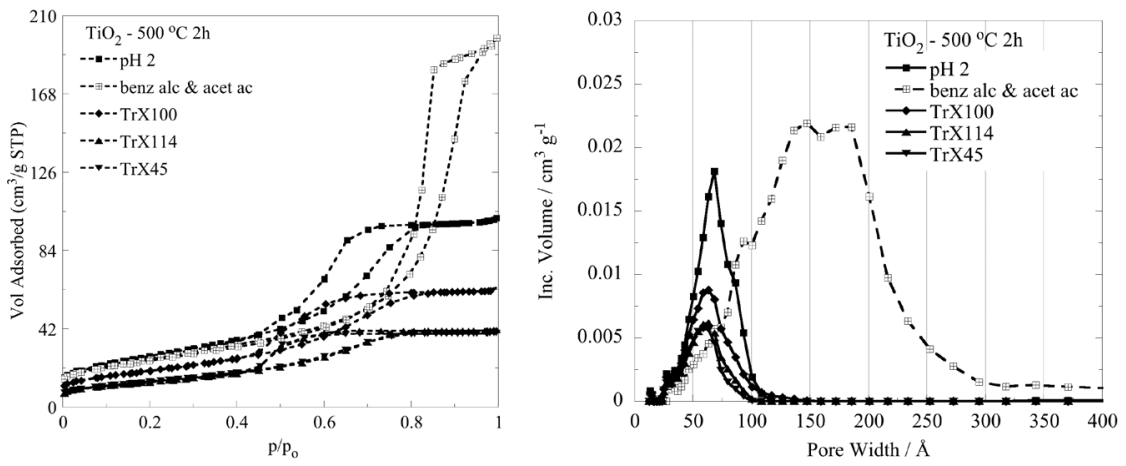

Figure 4. $\mathrm{N}_{2}$ ad/desorption isotherms and corresponding pores size distributions of $\mathrm{TiO}_{2}$ solids calcined at $500^{\circ} \mathrm{C}$ for $2 \mathrm{~h}$, prepared via matrix-assisted and matrix-free synthetic paths.

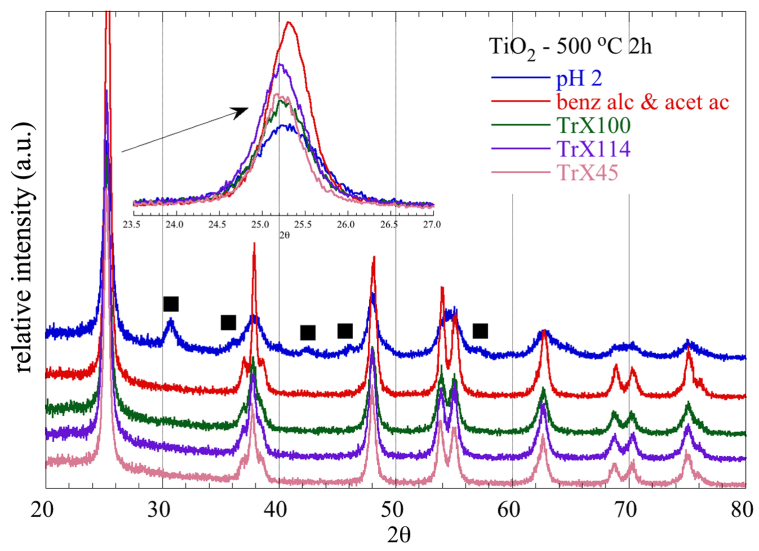

Figure 5. XRD diagrams of $\mathrm{TiO}_{2}$ particles calcined at $500^{\circ} \mathrm{C}$ for $2 \mathrm{~h}$ prepared via matrix-assisted and matrix-free synthetic paths.

Table 4. Surface characteristics of $\mathrm{TiO}_{2}$ solids calcined at $500^{\circ} \mathrm{C}$ for $2 \mathrm{~h}$ synthesized via matrix-assisted and matrix-free synthetic paths.

\begin{tabular}{ccccc}
\hline sample & $\begin{array}{c}\mathrm{SpA}_{\text {BET }} \\
\left(\mathrm{m}^{2} / \mathrm{g}\right)\end{array}$ & $\begin{array}{c}\mathrm{V}_{\mathrm{Sp}} \\
\left(\mathrm{cm}^{3} / \mathrm{g}\right)\end{array}$ & $\begin{array}{c}\mathrm{d}_{\mathrm{BJH}} \\
(\mathrm{nm})\end{array}$ & $\begin{array}{c}\mathrm{d}_{\text {DFT }} \\
(\mathrm{nm})\end{array}$ \\
\hline $\mathrm{TiO}_{2} \mathrm{pH}=2500^{\circ} \mathrm{C} 2 \mathrm{~h}$ & 94.2 & 0.156 & 4.61 & 6.81 \\
$\mathrm{TiO}_{2}$ benzalc \& acet ac $500^{\circ} \mathrm{C} 2 \mathrm{~h}$ & 87.9 & 0.302 & 10.52 & 15.9 \\
$\mathrm{TiO}_{2} \mathrm{TrX}-100500^{\circ} \mathrm{C} 2 \mathrm{~h}$ & 67.5 & 0.097 & 3.97 & 6.36 \\
$\mathrm{TiO}_{2} \mathrm{TrX}-114500^{\circ} \mathrm{C} 2 \mathrm{~h}$ & 46.1 & 0.064 & 3.63 & 6.24 \\
$\mathrm{TiO}_{2} \mathrm{TrX}-45500^{\circ} \mathrm{C} 2 \mathrm{~h}$ & 47.2 & 0.062 & 3.55 & 5.93 \\
\hline
\end{tabular}

colloidal aqueous system at $\mathrm{pH} 2$ become more intense with increasing calcination temperature and correspond to the crystalline planes of rutile [47] and are indicated by squares above the peaks at $2 \theta$ values $30.58^{\circ}, 36.09^{\circ}, 42.46^{\circ}, 45.94^{\circ}$ and $57.1^{\circ}$ corresponding to (101), (200), (111), (210) and (220) planes, respectively. At a calcination temperature of $700^{\circ} \mathrm{C}$, rutile peaks are slightly shifted and located at $2 \theta$ values of $27.39^{\circ}, 35.94^{\circ}, 39.13^{\circ}, 41.15^{\circ}, 43.91^{\circ}, 54.2^{\circ}, 56.52^{\circ}, 63.91^{\circ}$, $69.13^{\circ}$ and $69.85^{\circ}$, corresponding to (110), (101), (200), (111), (210), (211), 
(220), (002), (301) and (112) planes, respectively. Generally, independent of the synthetic path at increased calcination temperatures all $\mathrm{TiO}_{2}$ solid are gradually transformed from anatase to rutile, which is the thermodynamically more stable form of $\mathrm{TiO}_{2}$.

From the data in Table 5 it is obvious that the crystallinity of the solids is reduced by following order: solvothermal $>\operatorname{TrX}-114>\operatorname{TrX}-45>\operatorname{TrX}-100>\mathrm{pH} 2$. Regarding the crystallite size, the order is as follows: $\mathrm{pH} 2<\operatorname{TrX}-100<\operatorname{TrX}-114$ $<\operatorname{TrX}-45<$ solvothermal. These results are in line with the foregoing discussion and show that solids of colloidal systems present greater surface area compared to solids produced by the solvothermal method. The $\mathrm{TiO}_{2}$ samples from the Triton X-100 surfactant and solvothermal method are present higher thermal stability and resistibility to aggregation.

\subsection{Textural Changes of Titania Solids after Calcination at $700^{\circ} \mathrm{C}$}

X-ray diffractograms of solids prepared from five different synthetic methods and after calcination at $700^{\circ} \mathrm{C}$ are summarized in Figure 6 .

According to Figure 6, the diffraction peaks become more narrow and of higher intensity after calcination at $700^{\circ} \mathrm{C}$ due to proceeding crystallization and only the peaks of titania solids obtained from the solvothermal method and the

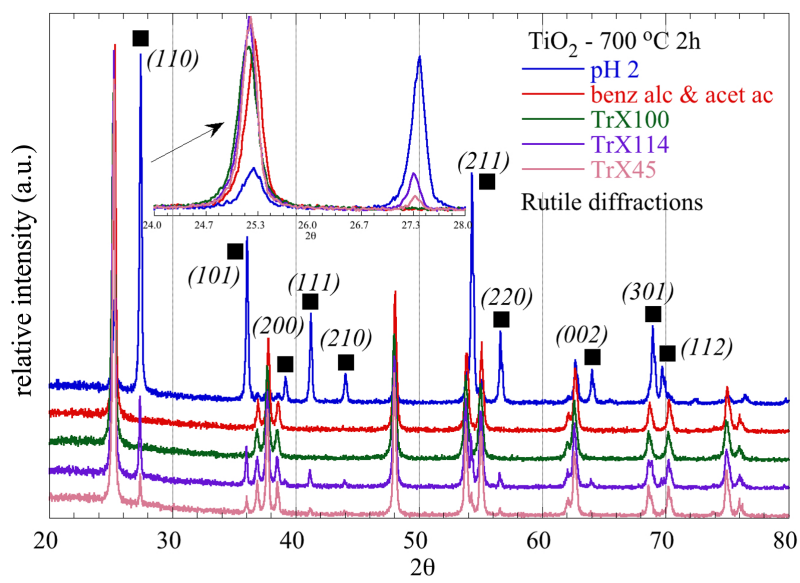

Figure 6. X-ray diffractograms of $\mathrm{TiO}_{2}$ solids calcined at $700^{\circ} \mathrm{C}$ for $2 \mathrm{~h}$ prepared via matrix-assisted and matrix-free synthetic paths.

Table 5. XRD data of $\mathrm{TiO}_{2}$ solids calcined at $500^{\circ} \mathrm{C}$ for $2 \mathrm{~h}$ from three different reverse micelles, aqueous colloidal method and solvothermal synthesis.

\begin{tabular}{ccccccc}
\hline sample & $\begin{array}{c}\mathrm{SpA}_{\text {BET }} \\
\left(\mathrm{m}^{2} / \mathrm{g}\right)\end{array}$ & $\begin{array}{c}2 \theta_{\text {Bragg }} \\
\left({ }^{\circ}\right)\end{array}$ & level & $\begin{array}{c}\mathrm{d}_{\text {Bragg }} \\
(\AA)\end{array}$ & $\begin{array}{c}\text { FWHM } \\
\left({ }^{\circ}\right)\end{array}$ & $\begin{array}{c}\mathrm{L}_{\text {XRD }} \\
(\mathrm{nm})\end{array}$ \\
\hline $\mathrm{TiO}_{2} \mathrm{pH}=2500^{\circ} \mathrm{C} 2 \mathrm{~h}$ & 94.2 & 25.32 & $(101)$ & 3.5151 & 0.8984 & 9.47 \\
$\mathrm{TiO}_{2}$ benz alc \& acet ac $500^{\circ} \mathrm{C} 2 \mathrm{~h}$ & 87.9 & 25.34 & $(101)$ & 3.5115 & 0.5718 & 14.88 \\
$\mathrm{TiO}_{2} \mathrm{TrX}-100500^{\circ} \mathrm{C} 2 \mathrm{~h}$ & 67.5 & 25.28 & $(101)$ & 3.5202 & 0.7132 & 11.93 \\
$\mathrm{TiO}_{2} \mathrm{TrX}-114500^{\circ} \mathrm{C} 2 \mathrm{~h}$ & 46.1 & 25.25 & $(101)$ & 3.5239 & 0.6439 & 13.22 \\
$\mathrm{TiO}_{2} \mathrm{TrX}-45500^{\circ} \mathrm{C} 2 \mathrm{~h}$ & 47.2 & 25.25 & $(101)$ & 3.5243 & 0.5753 & 14.79 \\
\hline
\end{tabular}


use of Triton X-100 correspond exclusively to crystalline planes of anatase [48] [49]. This is expected as these two materials are characterized by the highest thermal stability. In particular, the sample corresponding to Triton X-100 is the most stable of all and exhibits the smallest crystallite size, $\mathrm{L}_{\mathrm{XRD}}=28.72 \mathrm{~nm}$ (Table 6). It is obvious that for these materials the transformation of anatase to rutile takes place at temperatures greater than $700^{\circ} \mathrm{C}$. In the XRD diffractograms of the solids obtained from colloidal systems under acidic conditions the rutile peaks dominate as rutile is the titania structure, which is mainly formed under the given conditions [23]. The rutile appears at $2 \theta$ values: $27.39^{\circ}, 36.09^{\circ}, 39.13^{\circ}$, $41.3^{\circ}, 43.91^{\circ}, 54.2^{\circ}, 56.52^{\circ}, 64.06^{\circ}, 68.99^{\circ}$ and $69.71^{\circ}$ and are associated with crystalline diffraction levels (110), (101), (200), (111), (210), (211), (220), (002), (301) and (112), respectively [50]. The peaks that correspond to anatase structure are relatively very small.

The crystallite size [51] of titanium oxides increases as follows: $\operatorname{TrX}-100<$ $\operatorname{TrX}-114<$ solvothermal $<\operatorname{TrX}-45<\mathrm{pH}$ 2. Generally, data show that $\mathrm{TiO}_{2}$ solids obtained from the biggest amphiphilic $\operatorname{TrX}-100$ present the biggest thermal stability, followed by the intermediate surfactant $\operatorname{TrX}-114$ and the solids obtained from solvothermal method. Figure 7 shows FTIR spectra of titania samples prepared by the five different synthetic methods and calcined at $700^{\circ} \mathrm{C}$. From spectra (Figure 7) it is observed that band around $500 \mathrm{~cm}^{-1}$ is widened even more

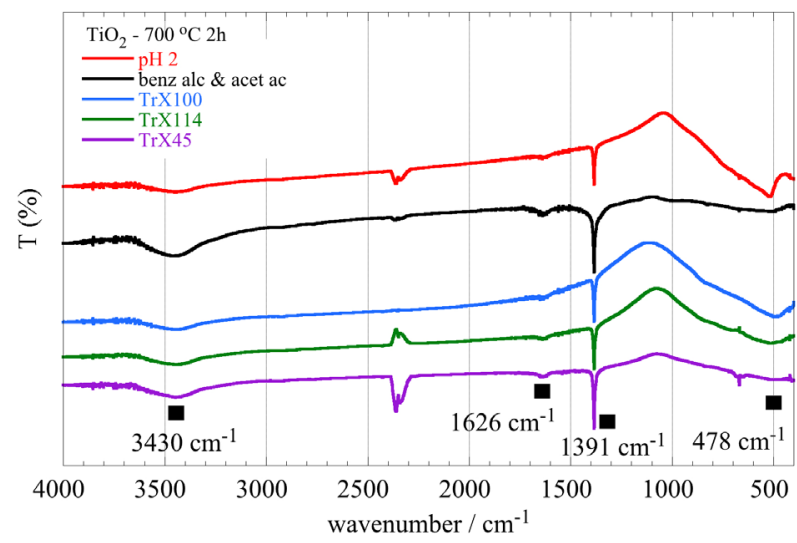

Figure 7. Infrared spectra of $\mathrm{TiO}_{2}$ materials calcined at $700^{\circ} \mathrm{C}$ for $2 \mathrm{~h}$ prepared via matrix-assisted and matrix-free synthetic paths.

Table 6. XRD measurements of $\mathrm{TiO}_{2}$ solids calcined at $700^{\circ} \mathrm{C}$ for $2 \mathrm{~h}$ prepared via matrix-assisted and matrix-free synthetic paths.

\begin{tabular}{cccccc}
\hline sample & $\begin{array}{c}2 \theta_{\text {Bragg }} \\
\left({ }^{\circ}\right)\end{array}$ & level & $\begin{array}{c}\mathrm{d}_{\text {Bragg }} \\
(\AA)\end{array}$ & $\begin{array}{c}\text { FWHM } \\
\left({ }^{\circ}\right)\end{array}$ & $\begin{array}{c}\mathrm{L}_{\text {XRD }} \\
(\mathrm{nm})\end{array}$ \\
\hline $\mathrm{TiO}_{2} \mathrm{pH}=2700^{\circ} \mathrm{C} 2 \mathrm{~h}$ & 27.43 & $(110)$ & 3.249 & 0.1956 & 43.7 \\
$\mathrm{TiO}_{2}$ benz alc \& acet ac $700^{\circ} \mathrm{C} 2 \mathrm{~h}$ & 25.32 & $(101)$ & 3.5154 & 0.2406 & 35.37 \\
$\mathrm{TiO}_{2} \mathrm{TrX}-100700^{\circ} \mathrm{C} 2 \mathrm{~h}$ & 25.23 & $(101)$ & 3.5271 & 0.2963 & 28.72 \\
$\mathrm{TiO}_{2} \mathrm{TrX}-114700^{\circ} \mathrm{C} 2 \mathrm{~h}$ & 25.25 & $(101)$ & 3.5246 & 0.2423 & 35.12 \\
$\mathrm{TiO}_{2} \mathrm{TrX}-45700^{\circ} \mathrm{C} 2 \mathrm{~h}$ & 25.26 & $(101)$ & 3.523 & 0.2221 & 38.31 \\
\hline
\end{tabular}


for solids obtained from reverse micelles and the solvothermal method compared to solids obtained from the aqueous colloidal system. In addition, the peaks at $521 \mathrm{~cm}^{-1}$ and $671 \mathrm{~cm}^{-1}$ in the spectra of samples of the colloidal system and the solid corresponding to smallest surfactant (Triton X-45), respectively, which are ascribed to vibrations of Ti-O-Ti and Ti-O bonds (Table 3 ) are characteristic for rutile phase [52] [53], supporting the previous results.

\subsection{DR-UV-Vis Solid State and SEM Studies of $\mathrm{TiO}_{2}$ Samples without Matrix Use Increasing Calcination Temperature}

From the graph in Figure 8, which shows the correlation between the energy gap and the calcination temperature for the studied samples, it is clear that these results are in agreement with corresponding results obtained from the isothermal adsorption, XRD and FTIR measurements.

Generally, titania solids with anatase structure present energy gap values above $3.2 \mathrm{eV}(3.23-3.6 \mathrm{eV})$, while rutile structure solids give an energy gap with lower values $(3.02-3.24 \mathrm{eV})$ [1]. According to the data in Table 2, Table 5 and Table 6 the smaller particle sizes are related with greater energy gaps as it is the case of the solids from intermediate surfactant $\operatorname{TrX}-114$ and colloidal aqueous systems at $\mathrm{pH} 2$. On the other hand, the solids corresponding to $\operatorname{TrX}-114$ show a big energy gap at $400^{\circ} \mathrm{C}$, which gradual declines with increasing temperature due to the gradual formation of the rutile phase. Materials from aqueous colloidal systems at $\mathrm{pH} 2$ at $400^{\circ} \mathrm{C}$ and $500^{\circ} \mathrm{C}$ present a big energy gap, that is greater than this of pure rutile, because of coexistence of two titania phases, anatase and rutile. This is observed also in the case of solids obtained from smallest amphiphilic $\operatorname{TrX}-45$ after calcination at $500^{\circ} \mathrm{C}$. At $600^{\circ} \mathrm{C}$ and $700^{\circ} \mathrm{C}$ materials obtained from colloidal systems at $\mathrm{pH} 2$ show the smallest value of energy gap, because the solids are quantitatively transformed to rutile.

Finally, the smallest changes of energy gap with increasing calcination temperature are observed for the two solids corresponding to the biggest surfactant

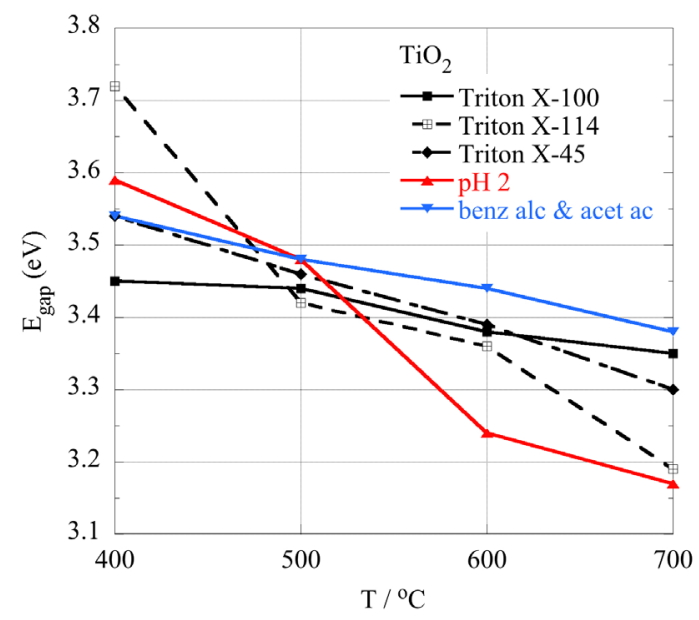

Figure 8. Correlation comparative graph of energy gap with calcination temperature of all the studied $\mathrm{TiO}_{2}$ samples increasing calcination temperature. 
TrX-100 and the solvothermal method. Moreover, the corresponding gaps have values above $3.2 \mathrm{eV}$, indicating that anatase is the predominant $\mathrm{TiO}_{2}$ phase. It is noteworthy, that solids from solvothermal method above $500^{\circ} \mathrm{C}$ present the greatest energy gap due to their increased thermal stability.

According to SEM measurements titania solids obtained from solvothermal methods are very well-formed and fine-grained powders with a mean size of aggregates around $48 \mu \mathrm{m}$ (Figure 9(a) and Figure 10(a)). The mean size value of $\mathrm{TiO}_{2}$ aggregates obtained using reverse micelles is $130 \mu \mathrm{m}$ [17]. According to SEM images (Figure 9 and Figure 10) increasing calcination temperature affects the mean size of particles obtained from aqueous colloidal systems and the values are 48,61 and $87 \mu \mathrm{m}$ for $400^{\circ} \mathrm{C}, 600^{\circ} \mathrm{C}$ and $700^{\circ} \mathrm{C}$, respectively. This indicates particle sintering process with increasing calcination temperature and hence materials with reduced thermal stability [23]. On the other hand, the mean size of aggregates obtained from the solvothermal method present smaller changes with increasing temperature with values of 48,47 and $56 \mu \mathrm{m}$ for $400^{\circ} \mathrm{C}$, $600^{\circ} \mathrm{C}$ and $700^{\circ} \mathrm{C}$, respectively, indicating high thermal stability of respective solids [41].

\section{Conclusions}

Figure 11 summarizes data of surface characteristics of titania solids prepared by five different methods and calcined at different temperatures.

From the diagrams above it can be concluded that:

1) Gels extraction by cyclohexane leads to significant increase of surface area and specific pore volume and improvement of surface characteristics (smaller crystalline size and smaller endo-atomic distances in crystal lattice) of produced titania solids from reverse micelles to an extent that they outweigh the solids prepared in matrix-free media.

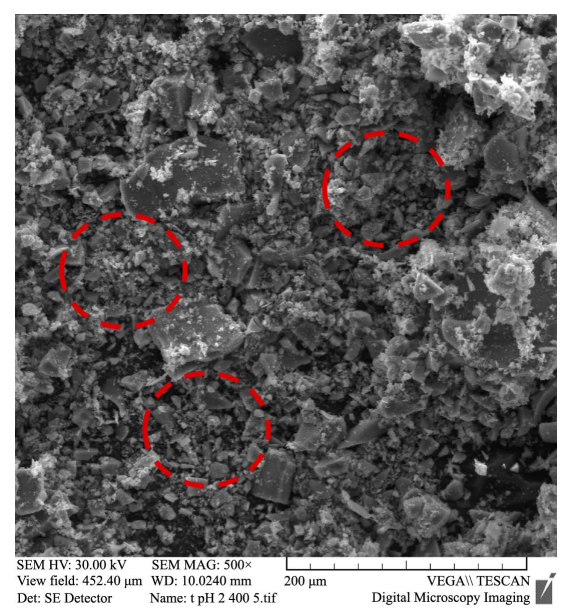

(a)

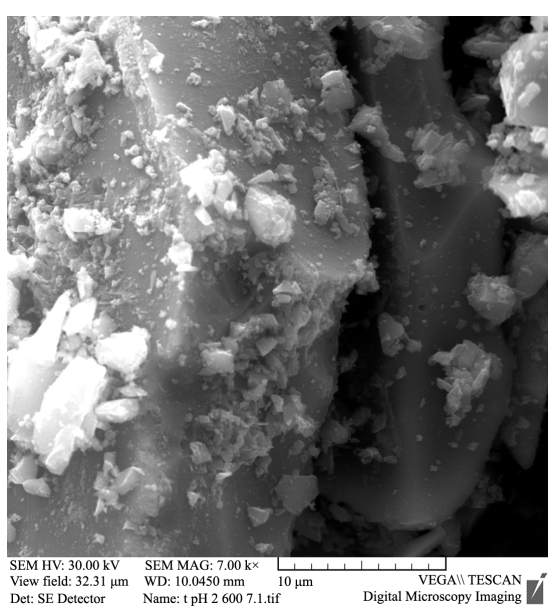

(b)

Figure 9. SEM images of titania solids obtained from aqueous colloidal systems and calcined at (a) $400^{\circ} \mathrm{C}$; and (b) at $600^{\circ} \mathrm{C}$ for $2 \mathrm{~h}$. Red circles highlight some clearly resolved titania crystallites. 


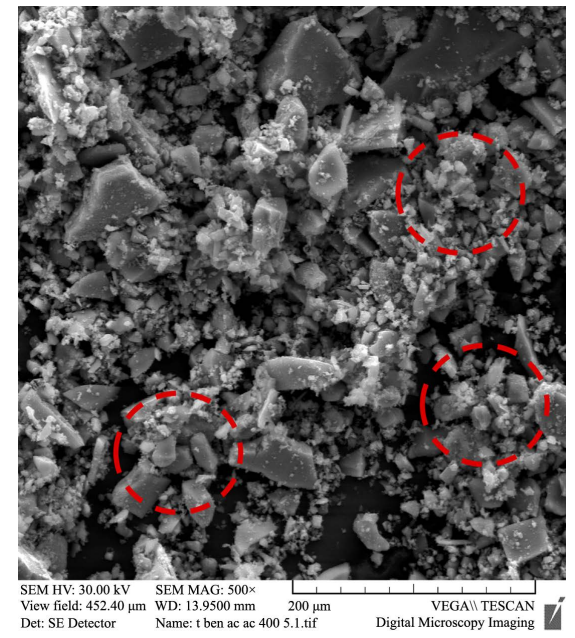

(a)

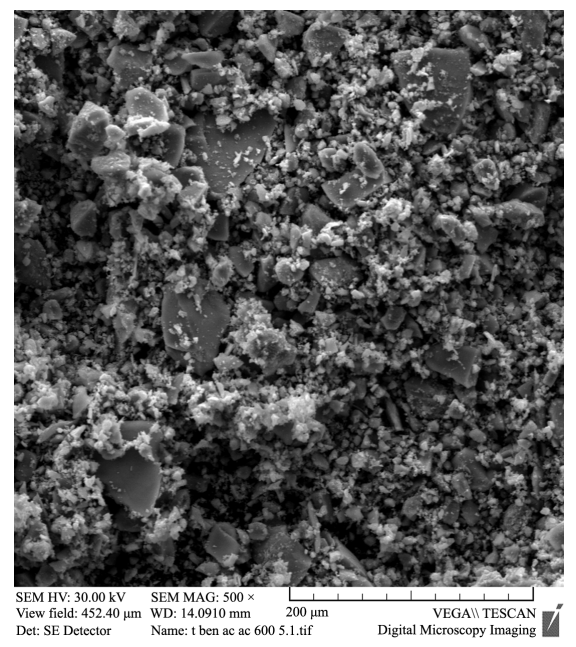

(c)

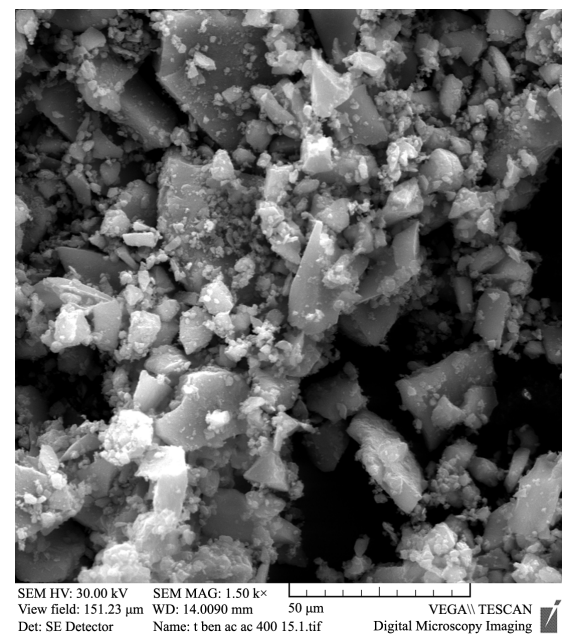

(b)

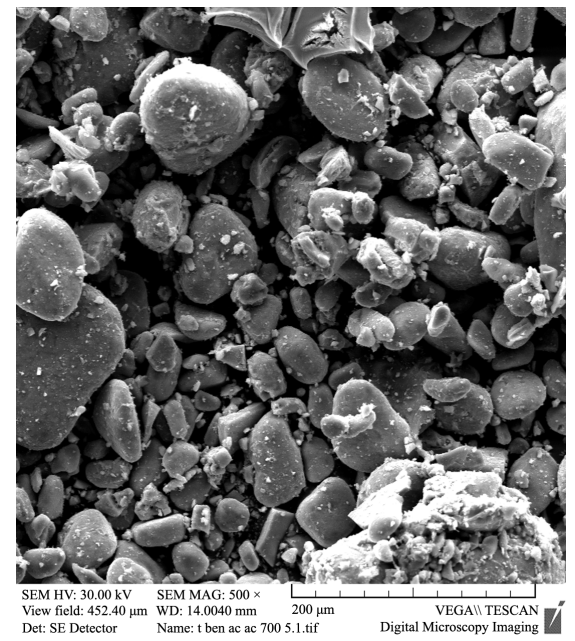

(d)

Figure 10. SEM images of $\mathrm{TiO}_{2}$ solids prepared by the solvothermal method and calcined at $400^{\circ} \mathrm{C}$ in (a) $500 \times$ and (b) $1500 \times$ magnifications; (c) at $600^{\circ} \mathrm{C}$ and (d) at $700^{\circ} \mathrm{C}$ for $2 \mathrm{~h}$ (500× magnification). Red circles highlight some clearly resolved titania crystallites.

2) At all calcination temperatures solids obtained using reverse micelles present smaller values of specific volume and mean pore diameter and higher values of endo-atomic distances compared to solids prepared in matrix-free media.

3) With increasing calcination temperature the crystal particle size increases at a slower rate for solids obtained using reverse micelles compared to those formed in matrix-free media.

4) The solids corresponding to the surfactant Triton X-100 and the solvothermal method are characterized by the greatest thermal stability and resistance to sintering.

The results discussed herein augur well for the use of organized media such as micelles, including reverse micelles, as microreactors for the synthesis of well characterized porous samples with desirable characteristics. 

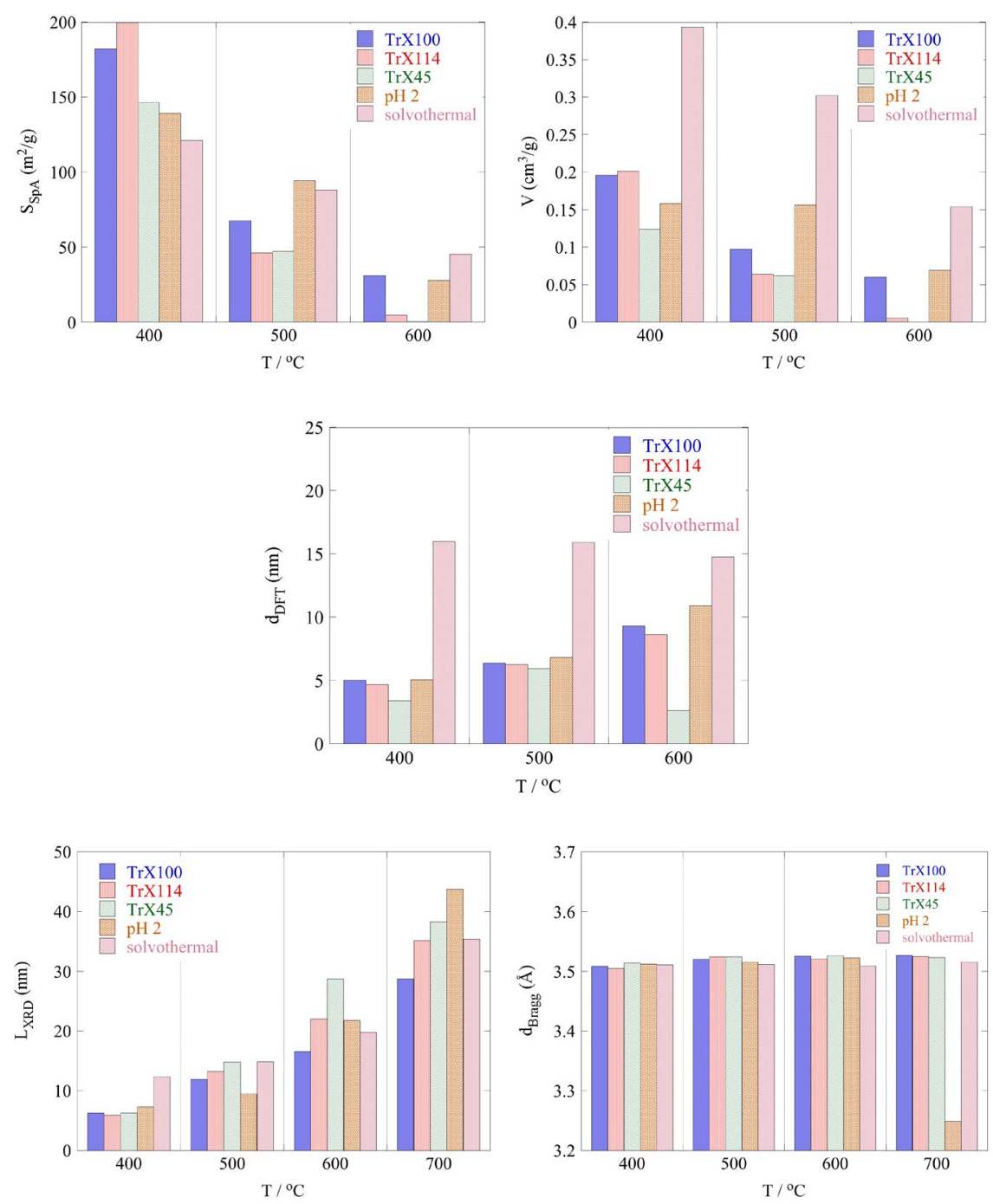

Figure 11. Calcination temperature effect on porosity $\left(\mathrm{SpA}, \mathrm{V}_{\mathrm{sp}}\right.$ and $\mathrm{d}_{\mathrm{DFT}}$ ) and XRD characteristics $\left(\mathrm{L}_{\mathrm{XRD}}\right.$ and $\mathrm{d}_{\mathrm{Bragg}}$ ) of $\mathrm{TiO}_{2}$ samples prepared via matrix-assisted and matrix-free synthetic paths.

\section{Acknowledgements}

We thank Professor Ioannis Giapintzakis and co-workers, for providing access to SEM facilities (Department of Mechanical \& Manufacturing Engineering at the University of Cyprus). Also, we thank Professor Ioannis Pashalidis for providing access to the DRUV-Vis solid state facilities.

\section{Conflicts of Interest}

The authors declare no conflicts of interest regarding the publication of this paper.

\section{References}

[1] Hanaor, D.A. and Sorrell, C.C. (2011) Review of the Anatase to Rutile Phase Transformation. Journal of Materials Science, 46, 855-874. 
https://doi.org/10.1007/s10853-010-5113-0

[2] Jaafar, N.F., Khairuddean, M. and Nordin, N. (2020) A Review on Recent Progression of Modifications on Titania Morphology and Its Photocatalytic Performance. Acta Chimica Slovenica, 67, 362-374. https://doi.org/10.17344/acsi.2018.5161

[3] Nursam, N.M., Tan, J.Z., Wang, X., Li, W., Xia, F. and Caruso, R.A. (2016) Mesoporous Nitrogen-Modified Titania with Enhanced Dye Adsorption Capacity and Visible Light Photocatalytic Activity. Chemistry Select, 1, 4868-4878. https://doi.org/10.1002/slct.201601234

[4] Chowdhury, I.H., Bose, P. and Naskar, M.K. (2016) A Facile Synthesis of Mesoporous Titania Cubes and Their Photocatalytic Application. Journal of Alloys and Compounds, 668, 56-64. https://doi.org/10.1016/j.jallcom.2016.01.167

[5] Chen, X. and Mao, S.S. (2007) Titanium Dioxide Nanomaterials: Synthesis, Properties, Modifications, and Applications. Chemical Reviews, 107, 2891-2959. https://doi.org/10.1021/cr0500535

[6] Truong, Q.D., Dien, L.X., Vo, D.V.N. and Le, T.S. (2017) Controlled Synthesis of Titania Using Water-Soluble Titanium Complexes: A Review. Journal of Solid State Chemistry, 251, 143-163. https://doi.org/10.1016/j.jssc.2017.04.017

[7] Zielinska-Jurek, A., Reszczynska, J., Grabowska, E. and Zaleska, A. (2012) Nanoparticles Preparation Using Microemulsion Systems. In: Najjar, R., Ed., Microemulsions - An Introduction to Properties and Applications, InTech, Rijeka, 229-250. https://doi.org/10.5772/36183

[8] Liying, H.E., Yumin, S.U., Lanhong, J. and Shikao, S.H.I. (2015) Recent Advances of Cerium Oxide Nanoparticles in Synthesis, Luminescence and Biomedical Studies: A Review. Journal of Rare Earths, 33, 791-799. https://doi.org/10.1016/S1002-0721(14)60486-5

[9] Bumajdad, A., Eastoe, J. and Mathew, A. (2009) Cerium Oxide Nanoparticles Prepared in Self-Assembled Systems. Advances in Colloid and Interface Science, 147, 56-66. https://doi.org/10.1016/j.cis.2008.10.004

[10] Parangi, T. and Mishra, M.K. (2019) Titania Nanoparticles as Modified Photocatalysts: A Review on Design and Development. Comments on Inorganic Chemistry, 39, 90-126. https://doi.org/10.1080/02603594.2019.1592751

[11] Paul, B.K. and Moulik, S.P. (2001) Uses and Applications of Microemulsions. Current Science, 80, 990-1001.

[12] Eastoe, J., Hollamby, M.J. and Hudson, L. (2006) Recent Advances in Nanoparticle Synthesis with Reversed Micelles. Advances in Colloid and Interface Science, 128-130, 5-15. https://doi.org/10.1016/j.cis.2006.11.009

[13] Pal, N. and Bhaumik, A. (2013) Soft Templating Strategies for the Synthesis of Mesoporous Materials: Inorganic, Organic-Inorganic Hybrid and Purely Organic Solids. Advances in Colloid and Interface Science, 189, 21-41. https://doi.org/10.1016/j.cis.2012.12.002

[14] Malik, M.A., Wani, M.Y. and Hashim, M.A. (2012) Microemulsion Method: A Novel Route to Synthesize Organic and Inorganic Nanomaterials: 1st Nano Update. Arabian Journal of Chemistry, 5, 397-417. https://doi.org/10.1016/j.arabjc.2010.09.027

[15] Khadzhiev, S.N., Kadiev, K.M., Yampolskaya, G.P. and Kadieva, M.K. (2013) Trends in the Synthesis of Metal Oxide Nanoparticles through Reverse Microemulsions in Hydrocarbon Media. Advances in Colloid and Interface Science, 197, 132-145. https://doi.org/10.1016/j.cis.2013.05.003 
[16] Paschalidou, P., Liatsou, I., Pashalidis, I. and Theocharis, C.R. (2017) Effect of Surface and Textural Characteristics on Uranium Adsorption by Nanoporous Titania. Journal of Radioanalytical and Nuclear Chemistry, 314, 1141-1147. https://doi.org/10.1007/s10967-017-5475-8

[17] Paschalidou, P. and Theocharis, C.R. (2018) Tuning the Porosity and Surface Characteristics of Nanoporous Titania Using Non-Ionic Surfactant Reverse Micelles. RSC Advances, 8, 29890-29898. https://doi.org/10.1039/C8RA05495A

[18] Paschalidou, P., Liatsou, I., Pashalidis, I. and Theocharis, C.R. (2018) The Effect of Surface Properties on the Uranium Adsorption by Mesoporous Ceria. Journal of Radioanalytical and Nuclear Chemistry, 318, 2193-2197. https://doi.org/10.1007/s10967-018-6195-4

[19] Paschalidou, P. and Theocharis, C.R. (2019) Surface Properties of Ceria Synthesised Using Triton-X Based Reverse Microemulsions. RSC Advances, 9, 7025-7031. https://doi.org/10.1039/C8RA08947G

[20] Paschalidou, P. and Theocharis, C.R. (2019) Comparison of Textural Characteristics of Ceria Solids Prepared via Triton X Reverse Micelles and in Situ Synthesized $\mathrm{Ce}\left(\mathrm{O}^{\mathrm{i} P r}\right)_{4}$ and $\mathrm{Ce}\left(\mathrm{O}^{\mathrm{i}} \mathrm{Pr}\right)_{3}$ Precursors. Materials Sciences and Applications, 10, 585-599. https://doi.org/10.4236/msa.2019.109042

[21] Gupta, S.M. and Tripathi, M. (2012) A Review on the Synthesis of $\mathrm{TiO}_{2}$ Nanoparticles by Solution Route. Central European Journal of Chemistry, 10, 279-294. https://doi.org/10.2478/s11532-011-0155-y

[22] Vorkapic, D. and Matsoukas, T. (1998) Effect of Temperature and Alcohols in the Preparation of Titania Nanoparticles from Alkoxides. Journal of the American Ceramic Society, 81, 2815-2820. https://doi.org/10.1111/j.1151-2916.1998.tb02701.x

[23] Mahshid, S., Ghamsari, M.S., Askari, M., Afshar, N. and Lahuti, S. (2006) Synthesis of $\mathrm{TiO}_{2}$ Nanoparticles by Hydrolysis and Peptization of Titanium Isopropoxide Solution. Semiconductor Physics Ouantum Electronics Optoelectronics, 9, 65-68. https://doi.org/10.15407/spqeo9.02.065

[24] Lim, C.S., Ryu, J.H., Kim, D.H., Cho, S.Y. and Oh, W.C. (2010) Reaction Morphology and the Effect of $\mathrm{pH}$ on the Preparation of $\mathrm{TiO}_{2}$ Nanoparticles by a Sol-Gel Method. Journal of Ceramic Processing Research, 11, 736-741.

[25] Lee, G.H. and Zuo, J.M. (2004) Growth and Phase Transformation of Nanometer-Sized Titanium Oxide Powders Produced by the Precipitation Method. Journal of the American Ceramic Society, 87, 473-479. https://doi.org/10.1111/j.1551-2916.2004.00473.x

[26] Uekawa, N., Endo, N., Ishii, K., Kojima, T. and Kakegawa, K. (2012) Characterization of Titanium Oxide Nanoparticles Obtained by Hydrolysis Reaction of Ethylene Glycol Solution of Alkoxide. Journal of Nanotechnology, 2012, Article ID: 102361. https://doi.org/10.1155/2012/102361

[27] Dastan, D. (2017) Effect of Preparation Methods on the Properties of Titania Nanoparticles: Solvothermal versus Sol-Gel. Applied Physics A, 123, Article No. 699. https://doi.org/10.1007/s00339-017-1309-3

[28] Yin, S., Fujishiro, Y., Wu, J., Aki, M. and Sato, T. (2003) Synthesis and Photocatalytic Properties of Fibrous Titania by Solvothermal Reactions. Journal of Materials Processing Technology, 137, 45-48. https://doi.org/10.1016/S0924-0136(02)01065-8

[29] Kang, M. (2003) Synthesis of $\mathrm{Fe} / \mathrm{TiO}_{2}$ Photocatalyst with Nanometer Size by Solvothermal Method and the Effect of $\mathrm{H}_{2} \mathrm{O}$ Addition on Structural Stability and Photodecomposition of Methanol. Journal of Molecular Catalysis A: Chemical, 197, 173-183. https://doi.org/10.1016/S1381-1169(02)00586-1 
[30] Kim, C.S., Moon, B.K., Park, J.H., Chung, S.T. and Son, S.M. (2003) Synthesis of Nanocrystalline $\mathrm{TiO}_{2}$ in Toluene by a Solvothermal Route. Journal of Crystal Growth, 254, 405-410. https://doi.org/10.1016/S0022-0248(03)01185-0

[31] Chen, D. and Xu, R. (1998) Solvothermal Synthesis and Characterization of $\mathrm{PbTiO}_{3}$ Powders. Journal of Materials Chemistry, 8, 965-968. https://doi.org/10.1039/a707546d

[32] Carp, O., Huisman, C.L. and Reller, A. (2004) Photoinduced Reactivity of Titanium Dioxide. Progress in Solid State Chemistry, 32, 33-177. https://doi.org/10.1016/j.progsolidstchem.2004.08.001

[33] Ramakrishnan, V.M., Natarajan, M., Santhanam, A., Asokan, V. and Velauthapillai, D. (2018) Size Controlled Synthesis of $\mathrm{TiO}_{2}$ Nanoparticles by Modified Solvothermal Method towards Effective Photo Catalytic and Photovoltaic Applications. Materials Research Bulletin, 97, 351-360.

https://doi.org/10.1016/j.materresbull.2017.09.017

[34] Vajedi, F.S. and Dehghani, H. (2016) Synthesis of Titanium Dioxide Nanostructures by Solvothermal Method and Their Application in Preparation of Nanocomposite Based on Graphene. Journal of Materials Science, 51, 1845-1854. https://doi.org/10.1007/s10853-015-9491-1

[35] Dastan, D., Chaure, N. and Kartha, M. (2017) Surfactants Assisted Solvothermal Derived Titania Nanoparticles: Synthesis and Simulation. Journal of Materials Science: Materials in Electronics, 28, 7784-7796. https://doi.org/10.1007/s10854-017-6474-9

[36] Yue, X., Xiang, J., Chen, J., Li, H., Qiu, Y. and Yu, X. (2020) High Surface Area, High Catalytic Activity Titanium Dioxide Aerogels Prepared by Solvothermal Crystallization. Journal of Materials Science \& Technology, 47, 223-230. https://doi.org/10.1016/j.jmst.2019.12.017

[37] Theocharis, C.R. (1993) Multifunctional Mesoporous Inorganic Solids. Vol. 400, Kluwer Academic Publishers, New York, 3-18. https://doi.org/10.1007/978-94-015-8139-4_1

[38] Thommes, M., Kaneko, K., Neimark, A.V., Olivier, J.P., Rodriguez-Reinoso, F., Rouquerol, J. and Sing, K.S. (2015) Physisorption of Gases, with Special Reference to the Evaluation of Surface Area and Pore Size Distribution (IUPAC Technical Report). Pure and Applied Chemistry, 87, 1051-1069. https://doi.org/10.1515/pac-2014-1117

[39] Dombrowski, R.J., Hyduke, D.R. and Lastoskie, C.M. (2000) Pore Size Analysis of Activated Carbons from Argon and Nitrogen Porosimetry Using Density Functional Theory. Langmuir, 16, 5041-5050. https://doi.org/10.1021/la990827a

[40] Masson, S., Holliman, P., Kalaji, M. and Kluson, P. (2009) The Production of Nanoparticulate Ceria Using Reverse Micelle Sol-Gel Techniques. Journal of Materials Chemistry, 19, 3517-3522. https://doi.org/10.1039/b820098j

[41] De Marco, L., Manca, M., Giannuzzi, R., Malara, F., Melcarne, G., Ciccarella, G., Zama, I., Cingolani, R. and Gigli, G. (2010) Novel Preparation Method of $\mathrm{TiO}_{2}$-Nanorod-Based Photoelectrodes for Dye-Sensitized Solar Cells with Improved Light-Harvesting Efficiency. The Journal of Physical Chemistry C, 114, 4228-4236. https://doi.org/10.1021/jp910346d

[42] Bhattacharyya, K., Wu, W., Weitz, E., Vijayan, B.K. and Gray, K.A. (2015) Probing Water and $\mathrm{CO}_{2}$ Interactions at the Surface of Collapsed Titania Nanotubes Using IR Spectroscopy. Molecules, 20, 15469-15487.

https://doi.org/10.3390/molecules200915469 
[43] Parra, R., Góes, M.S., Castro, M.S., Longo, E., Bueno, P.R. and Varela, J.A. (2008) Reaction Pathway to the Synthesis of Anatase via the Chemical Modification of Titanium Isopropoxide with Acetic Acid. Chemistry of Materials, 20, 143-150. https://doi.org/10.1021/cm702286e

[44] Socrates, G. (2004) Infrared and Raman Characteristic Group Frequencies: Tables and Charts. John Wiley \& Sons, London.

[45] Colomer, M.T., Velasco, M.J. and Jurado, J.R. (2006) Synthesis and Thermal Evolution of $\mathrm{TiO}_{2}-\mathrm{RuO}_{2}$ Xerogels. Journal of Sol-Gel Science and Technology, 39, 211-222. https://doi.org/10.1007/s10971-006-8207-z

[46] Suprabha, T., Roy, H.G., Thomas, J., Kumar, K.P. and Mathew, S. (2009) Microwave-Assisted Synthesis of Titania Nanocubes, Nanospheres and Nanorods for Photocatalytic Dye Degradation. Nanoscale Research Letters, 4, 144-152.

https://doi.org/10.1007/s11671-008-9214-5

[47] Prasad, K., Pinjari, D.V., Pandit, A.B. and Mhaske, S.T. (2010) Phase Transformation of Nanostructured Titanium Dioxide from Anatase-to-Rutile via Combined Ultrasound Assisted Sol-Gel Technique. Ultrasonics Sonochemistry, 17, 409-415. https://doi.org/10.1016/j.ultsonch.2009.09.003

[48] Niederberger, M., Bartl, M.H. and Stucky, G.D. (2002) Benzyl Alcohol and Titanium Tetrachloride a Versatile Reaction System for the Nonaqueous and Low-Temperature Preparation of Crystalline and Luminescent Titania Nanoparticles. Chemistry of Materials, 14, 4364-4370. https://doi.org/10.1021/cm021203k

[49] Cheng, T., Zhang, G., Xia, Y., Ji, Q., Xiao, Y., Wang, X., Wang, M., Liu, R., Qiu, B., Chen, G. and Chen, H. (2016) Template-Free Synthesis of Titania Architectures with Controlled Morphology Evolution. Journal of Materials Science, 51, 3941-3956. https://doi.org/10.1007/s10853-015-9713-6

[50] Patra, S., Andriamiadamanana, C., Tulodziecki, M., Davoisne, C., Taberna, P.L. and Sauvage, F. (2016) Low-Temperature Electrodeposition Approach Leading to Robust Mesoscopic Anatase $\mathrm{TiO}_{2}$ Films. Scientific Reports, 6, Article No. 21588. https://doi.org/10.1038/srep21588

[51] Swapna, M.V. and Haridas, K.R. (2015) Sonochemical Synthesis and Morphological Study of Nanocrystalline Rutile $\mathrm{TiO}_{2}$. Journal of the American Institute of Chemists, 88, 1-6.

[52] Song, K.C. and Pratsinis, S.E. (2000) Synthesis of Bimodally Porous Titania Powders by Hydrolysis of Titanium Tetraisopropoxide. Journal of Materials Research, 15, 2322-2329. https://doi.org/10.1557/JMR.2000.0334

[53] Farmer, V.C. (1974) Infrared Spectra of Minerals. Mineralogical Society, London. https://doi.org/10.1180/mono-4 